RESEARCH Note

\title{
Effect of different insecticides in the control of mango nut weevil (Sternochaetus mangiferae F.)
}

\author{
A. RAMA KRISHNA RAO \\ Acharya N.G. Ranga Agricultural University, Institute of Frontier Technology, Regional Agricultural Research Station, \\ TIRUPATHI (A.P.) INDIA \\ Email : rkraoandela@gmail.com
}

Article Info : Received : 11.02.2015; Accepted : 20.03.2015

Among the insecticides tested against nut weevil, carbaryl was effective in reducing the nut weevil infestation followed by endosulfan and malathion. Two applications of insecticides given at the time of flowering and marble size fruit stage were equally effective as in three sprays given at flowering marble size, fruit stage and advanced fruit development stage.

Key words : Mango, Nut weevil, Insecticides

How to cite this paper : Rao, A. Rama Krishna (2015). Effect of different insecticides in the control of mango nut weevil (Sternochaetus mangiferae F.). Asian J. Bio. Sci., 10 (1) : 116-118. 